\title{
ARSENICAL ENCEPHALOPATHY IN INDIAN TROOPS
}

BY

\author{
L. KRAINER, D. A. K. BLACK, R. J. McGILL, and N. V. RAO \\ (ReCEIVED 23RD July, 1946)
}

\section{Introduction}

UNTOWARD effects of antisyphilitic treatment, described as " arsenical encephalopathy," have been observed ever since trivalent arsenical compounds have been in use for the treatment of syphilis. Paul Ehrlich as early as 1914 believed the essential cause of the condition to be a dilatation of the small blood vessels of the brain which is followed by œdema and perivascular bleeding. He believes that the vascular change was due to some derivative of arsphenamine formed inside the body, as is suggested by the delay of several days before the characteristic reaction took place. Non-hæmorrhagic cases with necrosis and softening were described by Pollack and Riehl (1930). Demyelinating lesions were found by Dorothy Russell (1937). A comprehensive survey of the literature was made by Glaser and Imerman (1935). The condition has also occurred when the trivalent arsenicals have been used in conditions other than syphilis.

During 1943 and 1944 there were many fatalities among Indian troops undergoing treatment of syphilis with arsenicals. At the Third Medical Division's Conference, Southern Army, Poona, 1944, Krainer reported seventeen cases under the heading " arsenical encephalopathy."

In view of this high incidence an attempt was made to outline and classify the clinical picture and pathology of this condition with special reference to factors responsible for its appearance among Indian personnel. Reports of 184 cases were received from all over India. These included 37 cases observed in the Indian Military Hospital, Dunkirk.

\section{Analysis of Material}

An analysis of available case histories led to the following conclusions :

1. The incidence of arsenical encephalopathy in Indian troops is higher than the incidence rate of classical hæmorrhagic encephalopathy.

2. The incidence of this condition in Indian troops treated with weekly injections of N.A.B. is of the same order as the incidence in Indian civilians.

3. The increased incidence rate of this condition observed since 1943 is essentially the effect of treatment with bi-weekly, as opposed to the old standard treatment with weekly injections. (The dosage of arsenicals in the two treatment groups was uniformly standardized. Patients weighing $115 \mathrm{lb}$. and above received alternating 0.3 and 0.45 g. of N.A.B. Patients below $115 \mathrm{lb}$. received $0.3 \mathrm{~g}$. per injection.)

4. The increased incidence after bi-week!y injections refers to Madrassis and Mahrattas only, the incidence in other provincial groups showing no significant increase. It is noteworthy that the incidence rate is higher in the two provincial groups with the lower average body weight.

5. Malaria during or immediately before antisyphilitic treatment is an important factor in increasing the rate of arsenical encephalopathy.

Statistics.-The reported incidence of arsenical encephalopathy in the Army in India from August, 1943 , to March, 1945, was:

$$
\begin{array}{lllr}
\text { Indian cases } & \ldots & \ldots & 181 \\
\text { British cases } & . & \ldots & 3
\end{array}
$$

The Indian cases were distributed as follows :

$$
\begin{aligned}
& \begin{array}{llll}
\text { Madrassis .. } & \text {. } & \text {. } & 97
\end{array} \\
& \begin{array}{llll}
\text { Mahrattas .. } & \text {.. } & \text {.. } & 22
\end{array} \\
& \begin{array}{lllll}
\text { Others } & . & \ldots & \ldots & 62
\end{array}
\end{aligned}
$$$$
181
$$

Table I shows the total number of cases undergoing antisyphilitic treatment, and the incidence of arsenical encephalopathy, in the Indian Military Hospital, Dunkirk, and the Indian Military Hospital, Jalahalli. The average incidence rate in these groups is far higher than that recorded in the literature, for example, 0.2 per thousand in Glaser and Imerman's statistics. Statistics from the Madras General Hospital (1,000 cases treated with neoarsphenamines : Rajam and Rao, 1939) show a rate of 0.5 per cent., that is, twenty-five times Glaser and Imerman's figure.

Table II shows the incidence of arsenical encephalopathy classified according to weekly and bi-weekly injections. It shows that the incidence rate of arsenical encephalopathy is not due to a proportional increase in all groups. The incidence is six times the incidence following weekly injections in Madrassis and four times in Mahrattas, but it is only $\mathbf{0 . 2}$ per cent. higher in Indians from other provinces, which is below statistical significance. 
TABLE I

\begin{tabular}{|c|c|c|c|}
\hline $\begin{array}{l}\text { Provincial } \\
\text { group. }\end{array}$ & $\begin{array}{c}\text { Syphilis } \\
\text { under AST }\end{array}$ & $\begin{array}{c}\text { Cases of } \\
\text { arsenical } \\
\text { encephalo- } \\
\text { pathy }\end{array}$ & Inci- $\%$ \\
\hline 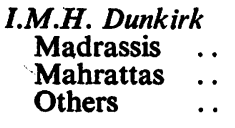 & $\begin{array}{l}657 \\
460 \\
792\end{array}$ & $\begin{array}{r}14 \\
16 \\
7\end{array}$ & $\begin{array}{l}2 \cdot 1 \\
3 \cdot 5 \\
0 \cdot 9\end{array}$ \\
\hline Total & 1,909 & 37. & 1.9 \\
\hline $\begin{array}{l}\text { I.M.H. Jalahalli } \\
\text { Madrassis } \quad . \\
\text { Others } \\
\text { Mahrattas (not } \\
\text { separa tely } \\
\text { recorded) }\end{array}$ & $\begin{array}{r}1,548 \\
820\end{array}$ & $\begin{array}{r}31 \\
8\end{array}$ & $\begin{array}{l}2 \cdot 0 \\
1 \cdot 0\end{array}$ \\
\hline Total & 2,368 & 39 & $1 \cdot 6$ \\
\hline
\end{tabular}

Comparison of figures for the Indian Military Hospital, Dunkirk, and the Indian Military Hospital, Jalahalli, from January, 1944, to March, 1945.

The average weight of Madrassis and Mahrattas is below that of the group classified as "Others" (see Table III).

Social Incidence.-Of the patients under antisyphilitic treatment, 11.1 per cent. (212 out of 1,909 cases) were non-commissioned officers; only three of these developed arsenical encephalopathy. No case was recorded in a Viceroy-commissioned officer or gazetted Indian officer. It was considered that at least part of the high racial incidence in Indians is social incidence. It seems a reasonable conjecture that a deficient diet plays a part. Lydon (1944) has stressed the possible relationship of Vitamin $B_{1}$ and $C$ deficiency. The poor Madrassi diet is known for its deficiencies (McCarrison, 1921).

Malaria.-Thirteen cases out of a series of 1,909 developed benign tertian malaria during or shortly before undergoing antisyphilitic treatment; of these, four developed arsenical encephalopathy, giving an incidence of 30.8 per cent. as against 1.9 per cent.

Time of Onset of Arsenical Encephalopathy.-The intervals between the first injection of N.A.B. and the onset of arsenical encephalopathy can be seen in graphs $1,2,3$, and 4 .

The influence of the stage of the syphilitic infection on the incidence rate of arsenical encephalopathy is shown in Table IV, from which it can be seen that the incidence of arsenical encephalopathy in sero-positive primary and secondary syphilis is no higher than in sero-negative primary syphilis. On the contrary, the incidence rate in sero-negative primary syphilis is higher than in the other two groups of this series, the difference being below statistical significance.

Mortality Rate.-The mortality rate is shown in Table V. The mortality rate of arsenical encephalopathy was 76 per cent. in the series of Glaser and Imerman; it will be seen, therefore, that the mortality rate is lower in Indian troops, but the fatalities from encephalopathy in Indian troops are 75.9 per cent. of all fatalities during antisyphilitic treatment, as against 50 per cent. in the series of Cole and others (1931).

\section{The Clinical Picture}

This description is based upon the analysis of 37 cases observed in the Indian Military Hospital, Dunkirk. In general a fairly definite sequence of events could be outlined.

Prodromal Symptoms.-In a few cases, several days before the onset the patient exhibited headache, fever with a negative blood slide, and malaise. This was often associated with excessive thirst, a feeling of chilli $\frac{\text { ते }}{10}$ ness and exhaustion, and, on occasion, abdominal colios and epigastric tenderness. These became enough to $\mathrm{B}$ warn us that encephalopathy threatened.

Onset.-Gradual and sudden types occurred in approximately equal numbers; the latter commenceg as an epileptic fit followed by evidence of cerebrak. irritation.

Progress.-For the purpose of description four subsequent stages may be distinguished. For the sake of convenience they may be called, somewhat arbitrarily, stage one, two, three, and coma. A patient may never progress beyond stage one or stage two.

The essential feature of stage one is that the patient, though mentally retarded, is still accessible and is able to walk about. He may complain of malaise and lethargy, and often of fear; visual hallucinations and confusion may be prominent. He tends to wander from his bed. On examination the pupils are found to be

TABLE II

\begin{tabular}{|c|c|c|c|c|c|c|c|c|c|c|c|c|c|c|}
\hline \multirow{2}{*}{\multicolumn{3}{|c|}{$\begin{array}{l}\text { Frequency of } \\
\text { injections }\end{array}$}} & \multicolumn{4}{|c|}{ No. of cases of AST } & \multicolumn{4}{|c|}{ Number of A.E. } & \multicolumn{4}{|c|}{ Incidence rate $\%$} \\
\hline & & & $\begin{array}{l}\text { Mad- } \\
\text { rassis }\end{array}$ & $\begin{array}{l}\text { Mah- } \\
\text { rattas }\end{array}$ & Others & Total & $\begin{array}{l}\text { Mad- } \\
\text { rassis }\end{array}$ & $\begin{array}{l}\text { Mah- } \\
\text { rattas }\end{array}$ & Others & Total & $\begin{array}{l}\text { Mad- } \\
\text { rassis }\end{array}$ & $\begin{array}{l}\text { Mah- } \\
\text { rattas }\end{array}$ & Others & Total \\
\hline Weekly & 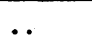 & & 342 & 173 & 380 & 895 & 2 & 2 & 3 & 7 & 0.6 & $1 \cdot 2$ & 0.8 & 0.8 \\
\hline i-weekly. & . & 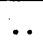 & 315 & 287 & 412 & 1014 & 12 & 14 & 4 & 30 & $3 \cdot 8$ & 4.9 & $1 \cdot 0$ & $3 \cdot 0$ \\
\hline
\end{tabular}

Incidence of arsenical encephalopathy classified according to frequency of injections. 
TABLE III

\begin{tabular}{|c|c|c|c|}
\hline \multirow{2}{*}{ Provincial group } & \multirow{2}{*}{$\begin{array}{l}\text { No. of } \\
\text { cases }\end{array}$} & \multicolumn{2}{|c|}{ Weight (lb.) } \\
\hline & & Average & Range \\
\hline $\begin{array}{ll}\text { Madrassis under AST } & \ldots \\
\text { Madrassis A.E. } & \text {. } \\
\text { Mahrattas under AST } & \text {. } \\
\text { Mahrattas A.E. } & \text { ". } \\
\text { "Others" under AST } & \text {. } \\
\text { "Others" A.E. .. } & \text {.. }\end{array}$ & $\begin{array}{r}657 \\
14 \\
460 \\
16 \\
792 \\
7\end{array}$ & $\begin{array}{r}99 \\
103 \\
103 \\
92 \\
108 \\
114\end{array}$ & $\begin{array}{r}78-148 \\
95-120 \\
83-141 \\
90-110 \\
97-157 \\
100-120\end{array}$ \\
\hline
\end{tabular}

Classification of cases under antisyphilitic treatment and cases of arsenical encephalopathy, according to provincial group and body weight.

small and to react to light. There may be a general hyperæsthesia, but plantar reflexes and deep reflexes are normal while the abdominals may be absent. Questions are answered correctly, but there is a noticeable delay.

In the second stage the patient is more drowsy but can be roused. $\mathrm{He}$ is, however, unco-operative and resists examination. There is often hyperæsthesia and fever. Examination reveals small irregular pupils reacting to light. The deep reflexes are increased with unsustained ankle clonus. The superficial reflexes are lost and there is an upgoing toe.

The third stage is always pyrexial with increased respiratory rate, stertor, hiccough, and loss of sphincter
TABLE IV

\begin{tabular}{c|c|c|c|c}
\hline & \multicolumn{2}{|c|}{$\begin{array}{c}\text { No. of cases } \\
\text { of A.S.T. }\end{array}$} & A.E. & A.E. \\
Stage of syphilis & \multicolumn{2}{|c|}{$\begin{array}{c}\text { A.E. } \\
\text { No. }\end{array}$} \\
\cline { 2 - 5 } & Weekly & $\begin{array}{c}\text { Bi- } \\
\text { weekly }\end{array}$ & & - \\
\hline Sero-negative primary & 166 & 176 & 10 & 2.9 \\
Sero-positive primary & 495 & 561 & 15 & 1.4 \\
Secondary .. & 234 & 277 & 12 & $2 \cdot 3$ \\
\hline
\end{tabular}

The influence of the stage of the syphilitic infection on the incidence rate of arsenical encephalopathy.

cerebrospinal fluid pressure varied from 45 to $190 \mathrm{~mm}$. water, the average being 87 . The cerebrospinal fluid cell count ranged from 0 to 40 , being under 4 in 32 cases, from 5 to 10 in 3 cases, and 11 and above in 2 cases. The total protein ranged from 70 to $900 \mathrm{mg}$. per $100 \mathrm{c.cm}$. average $207 \mathrm{mg}$. It was noted that no case with over $300 \mathrm{mg}$. per $100 \mathrm{c.cm}$. survived.

The cerebrospinal fluid Wassermann reaction was negative in 17 cases and positive in 3.

The white cell count ranged from 5,000 to 21,000 per c.mm.

Albuminuria was present in 12 out of 37 cases.

\section{Treatment}

Treatment consisted of general nursing and a standard treatment as recommended by Army Directive, which included: venesection, lumbar puncture, adrenaline, morphia, atropine, and the routine use of intravenous calcium gluconate. The results of this treatment as well as of additional proceduresadministration of sodium thiosulphate and oxygen, were inconclusive. Case records illustrative of the types of cases encountered are appended.

\section{Case Reports}

control. There are frequent fits resembling status epilepticus. There may be teeth-grinding, moaning, etc. Examination shows dilated pupils reacting sluggishly to light, later becoming fixed. The deep reflexes and the swallowing reflex are still present. Kernig's and Babinski's sign may be present.

This is followed by deep coma in which the respiratory rate may exceed sixty per minute. The deep reflexes are lost. The pupils are fixed, and there is a tendency to hyperpyrexia. Every case which reached this stage died.

Special Examinations.-Examination of the fundus in ten cases showed no abnormalities, and blood pressure was within normal limits, the average being $117 / 73 \mathrm{~mm}$. Hg. In ten cases that had reached stage three the
Case 1.-A Madrassi Havildar (Sergeant), aged 19 years, weight $90 \mathrm{lb}$., was admitted to hospital on Sept. 17, 1944, with a generalized papular rash of 8 days' duration and a sore in the right inguinal region. Blood Wassermann and Kahn reactions were negative. He received four injections of N.A.B. bi-weekly, to a total of $1.2 \mathrm{~g}$.

On Oct. 13, eleven days after the first injection he was apprehensive, restless, and groaning, but conscious and able to answer questions. He was incontinent of urine. The temperature was $98.4^{\circ} \mathrm{F}$., the pulse rate 84 , and the respiration rate 26 per minute. Babinski's sign was negative. By Oct. 14 he was dazed, refused to speak, and made occasioral twitching movements with the 
TABLE V

\begin{tabular}{lr|c|c|c}
\hline \multicolumn{2}{c|}{$\begin{array}{c}\text { Complications } \\
\text { of AST }\end{array}$} & $\begin{array}{c}\text { No. of } \\
\text { cases }\end{array}$ & $\begin{array}{c}\text { Fatal } \\
\text { cases }\end{array}$ & $\begin{array}{c}\text { Fatality } \\
\text { rate \% }\end{array}$ \\
\hline A.E. ‥ & $\ldots$ & 37 & 20 & $54 \cdot 1$ \\
Other than A.E. .. & 49 & 6 & $12 \cdot 2$ \\
\hline
\end{tabular}

Mortality

fingers. The left pupil was larger than the right, both reacting to light; there was bilateral nystagmus. The deep reflexes were present, and the plantar reflexes extensor. He was still incontinent of urine. The cerebrospinal fluid protein was $100 \mathrm{mg}$. per $100 \mathrm{c.cm}$.

By Oct. 16 the patient had recovered. This was a mild case, with fear as an early symptom.

Case 2.-A Madrassi Sepoy, aged 22 years, weight $95 \mathrm{lb}$., who had had a penile sore one year previously and now had a scar from the old chancre, and whose blood Wassermann and Kahn reactions were positive, was given four injections of N.A.B. bi-weekly, totalling $1.2 \mathrm{~g}$. On Sept. 12, 1944, twelve days after the first injection, he suddenly fell while on fatigue. He was unconscious, and had hæmetemesis. The temperature was $100 \cdot 2^{\circ} \mathrm{F}$, and he frothed at the mouth. There were choreoid movements of limbs and head, and athetosis of the hands. The eyes showed conjugate deviation to the left. The pupils were moderately dilated and equal, and reacted to light. Babinski's reflex was negative. The deep reflexes were sluggish, and the abdominal reflexes absent. The right plantar reflex was extensor, the left equivocal. There was incontinence of urine. The cerebrospinal fluid pressure was $70 \mathrm{~mm}$. water, five, cells, protein $100 \mathrm{mg}$. per $100 \mathrm{c.cm}$.

On Sept. 13 the patient was grinding his teeth and had occasional convulsions. On Sept. 15 he was conscious and responded to questions, but with some delay. Abdominal reflexes were absent and plantar reflexes flexor ; he was incontinent of urine on this day and the next, but by Sept. 19 he felt well.

This was a typical case with sudden onset.

Case 3.-A Sepoy, aged 36, weight $120 \mathrm{lb}$., classified as "Others," was admitted to hospital on June 4, 1944, with inguinal bubo. Routine blood Wassermann and Kahn examinations were positive. He received five injections of N.A.B. at weekly intervals, total $1.8 \mathrm{~g}$.
On July 6, seventeen days after the first injection, he was found wandering aimlessly and was conducted back to the ward. The next day he looked vacant and was unable to reply to questions ; five hours later he was found unconscious. The temperature was $102^{\circ} \mathrm{F}$., the respiration rate 36 per minute, and he was bathed in sweat. Examination of the eyes showed the pupils moderately dilated, reacting to light, left external rectus palsy, and normal fundi. Babinski's sign was positive. Jaw clonus was present, and there was fibrillation of masseters and temporales, but no paresis. There were intermittent clonic movements of the right arm and of both legs, with continuous athetoid movements of hands and feet. The deep reflexes were increased, the abdominal reflexes absent, and the plantar reflexes extensor. There was incontinence of urine. The blood pressure was $140 / 80 \mathrm{~mm}$. $\mathrm{Hg}$, and the cerebrospinal fluid contained $210 \mathrm{mg}$. of protein per $100 \mathrm{c.cm}$.

By July 8 the patient was in deep coma, with pupils contracted and fixed, and all deep reflexes absent. His condition rapidly worsened, and he died.

This case demonstrates the "three stages" preceding the coma which leads to death.

Case 4.-A Pioneer, age and weight unknown, classitied as "Others," was admitted on April 4, 1944, to the $\vec{\circ}$ venereal disease centre, Serampore. The blood is Wassermann and Kahn reactions were positive. Het $\overrightarrow{-}$ received three injections of "Evarsan" at bi-week intervals, a total of $0.9 \mathrm{~g}$., and had no reaction.

On April 18 the blood Kahn reaction was still positiv $\stackrel{9}{\rightarrow}$ On April 25, thirteen days after the first injection, tle $Z$ patient took a normal meal and then collapsed where tec was sitting, after which he was unable to answer questions. He was not unconscious, but stupid (stage two). received $1 \mathrm{c.cm}$. of adrenaline intramuscularly at $14.4 \Phi$ hours, the dose being repeated at 15.10 hours when tee also had 5 per cent. glucose saline, $20 \mathrm{c.cm}$., and calcium $\nsubseteq$ gluconate, $10 \mathrm{c.cm}$. intramuscularly, and a lumbar. puncture. He improved, and next day was fully. conscious but weak; he was given glucose and milk and kept in bed.

On April 27 he was found collapsed, bathed in sweat, and quite unconscious at approximately 06.15 hours.

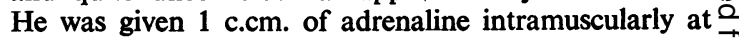
06.30 hours, at 08.30 hours, and thereafter at three- $\overrightarrow{\vec{O}}$ hourly intervals ; also 50 per cent. glucose, $20 \mathrm{c.cm}$., intravenously at 07.00 hours, and $100 \mathrm{c.cm}$. at 15.00 ?

TABLE VI

\begin{tabular}{|c|c|c|c|c|c|c|c|c|}
\hline \multirow[t]{2}{*}{ Diagnosis } & & \multirow{2}{*}{$\begin{array}{l}\text { No. of } \\
\text { cases }\end{array}$} & \multirow{2}{*}{$\begin{array}{c}\text { Interval } \\
\text { between } \\
\text { last injection } \\
\text { and death } \\
\text { in days }\end{array}$} & \multirow{2}{*}{$\begin{array}{c}\text { Total } \\
\text { N.A.B. } \\
\text { given in } \mathrm{g} .\end{array}$} & \multicolumn{3}{|c|}{$\begin{array}{l}\text { Arsenic contents } \\
\text { in } \mathrm{mg} . \%\end{array}$} & \multirow{2}{*}{$\begin{array}{l}\text { Arsenic } \\
\text { content of } \\
\text { brain in } \% \\
\text { of liver } \\
\text { As content }\end{array}$} \\
\hline & & & & & Brain & Liver & Kidney & \\
\hline Arsenical encephalopathy & .. & 6 & 4 & 1,35 & $0 \cdot 17$ & 0.58 & 0.66 & $29 \cdot 3$ \\
\hline Other fatalities during AST & .. & 3 & 15 & 2,95 & 0.026 & 0.3 & 0.43 & $\overline{8.7}$ \\
\hline
\end{tabular}

Arsenic contents of tissues; average values. 


\section{GRAPH 2}

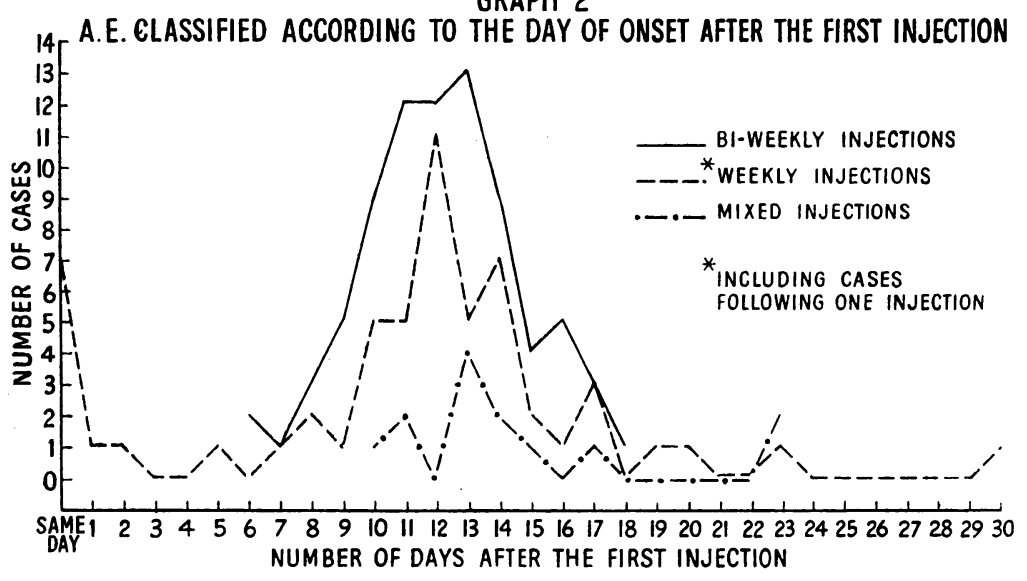

In the midbrain there was mild thickening of the meninges, mild proliferation of the astroglia subpial, and perivascular necrosis around some of the large rami perforantes, with demyelination. In the cerebellum there was hyperæmic congestion of the meninges. In the cortex the meninges were moderately thickened, with scanty round-cell infiltration. The meningeal vessels were congested, and there was hyperæmic congestion of the cortex and of the subcortical white matter. There was no evidence of hæmorrhage. The round cells in the meninges were lymphocytes and histiocytes.

This was a case of relapse.

Case 5.-A Sepoy, age and hours. Fischer's solution, 100 c.cm., was administered at $\mathbf{1 0 . 3 0}$ hours, and 5 per cent. glucose saline by drip method intravenously, starting at 08.30 hours and continuing up to 18.00 hours-total $200 \mathrm{c.cm}$.

He died at 09.19 hours on the following day after having developed hyperpyrexia. The cerebrospinal fluid was clear and colourless, with 48 lymphocytes and 12 polymorphs per c.cm., protein $100 \mathrm{mg}$. per $100 \mathrm{c.cm}$. The Nonne-Appelt reaction was weakly positive, the Wassermann positive. There was no albumin, but some sugar in the urine. The white blood count was 5,800 per c.mm., polymorphs 65 per cent., lymphocytes 30 per cent., monocytes 4 per cent., eosinophils 1 per cent. Bleeding and clotting times were normal. Red blood cells were 4,800,000 per c.mm., Hb 90 per cent., and there were no malaria parasites.

At necropsy examination twenty-three hours after death the body was seen to be that of a well-nourished young Indian male with healing pubic region sores. There was a faded corymbse secondary rash, postmortem bruising and discoloration, and slight generalized adenitis. The tongue, pharynx, fauces, and trachea showed considerable post-mortem changes. There were no adhesions in the lungs, but basal congestion with marked crepitus. The pericardium, aorta, and coronary arteries were normal, and also the œsophagus, stomach, and intestines.

Histological examination of the liver showed focal round-cell infiltration with peripheral histiocytic and fibroblastic proliferation and occasional central necrosis ; a few histocytic giant cells, and also symplasmic giant cells formed by degenerating liver cells, were seen. Reticulum stain showed overgrowth of delicate reticulum fibres in the areas of necrosis. There was regeneration of liver cells in the neighbourhood under formation of pseudolobules and there were also foci of scar formation. A diagnosis of syphilitic hepatitis with early syphilitic cirrhosis was made.

The medulla oblongata showed occasional perivascular round cells, but no other pathological changes were detected. weight unknown, was admitted to the venereal disease centre on Dec. 9, 1943, with a penile sore. The blood Wassermann was strongly positive, the Kahn positive. He had two injections of N.A.B. at a week's interval, total $0.6 \mathrm{~g}$.

On Dec. 26, eleven days after the first injection, he was found to be behaving abnormally. Pupils were normal and reacted to light. There was retention of urine but no rise of temperature. He died eight hours later.

Necropsy showed an Indian male of average build, with bloodstained froth round the mouth. The pleura was free, but there was œdema of the lungs. Heart, abdominal cavity, liver, spleen, bladder, and prostate were normal. The brain showed confluent punctate hæmorrhages and hæmorrhagic softening in the pes of the pons.

Histological examination of the cortex and subcortical GRAPH 3

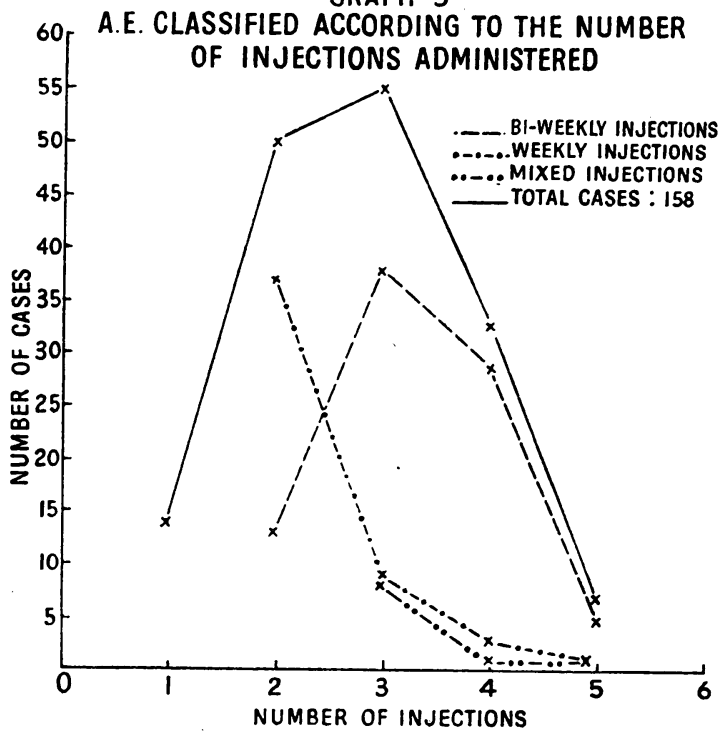




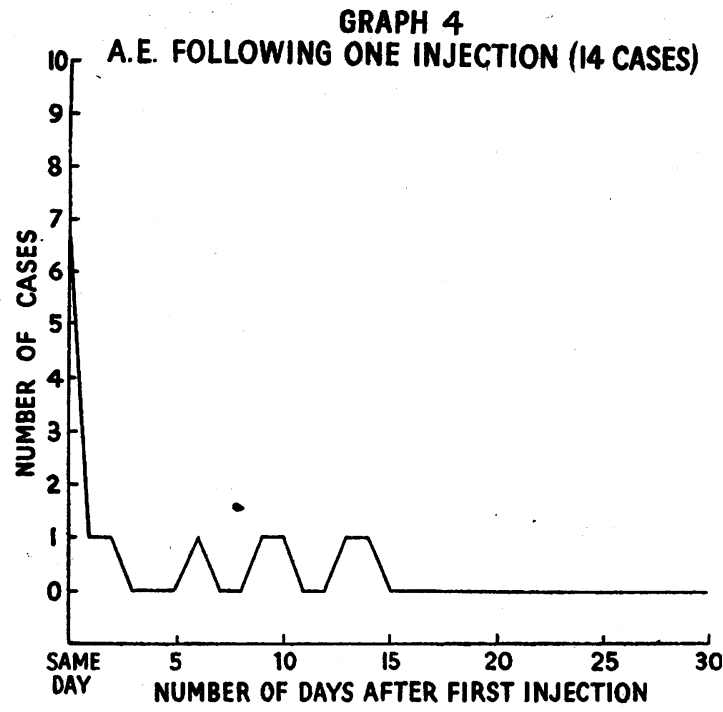

white matter showed hyperæmic congestion. The subcortical vessels showed severe distention of the perivascular space by homogeneous viscous proteinic material. There were scanty round cells perivascularly. Edema was present.

The pes pontis showed engorgement of the large vessels and changes of the same type as described in the cortex. There was also extensive confluent capillary hæmorrhage of the ring type, and occasional perivascular hæmorrhage. Extensive necrobiotic changes existed in the neighbouring brain substance with a tendency towards homogenization. There was œdema.

The liver showed hyperæmic congestion, occasional fatty change, and marked periportal round-cell infiltration.

The spleen showed hæmorrhagic patches in the pulp.

This was a case of " hæmorrhagic arsenical encephalopathy."

\section{Pathology}

This report is based on nineteen post-mortem examinations with subsequent histological examination. The central nervous system and internal organs of forty-one additional cases were also examined histologically. In view of the fact that the histological lesions are the same as in classical " hæmorrhagic arsenical encephalopathy" and differ only in numbers and intensity, the account will be brief.

\section{MACROSCOPIC EXAMINATION}

External Appearance.-A healing or healed penile sore was a common feature.

SKull AND BRAIN.-Congestion of the meningeal veins was a constant feature. The most frequent findings were : a mild swelling of the brain, a pale appearance of the white matter ; the grey matter was either normal or congested. The brain was not "wet." Only one case showed a pressure cone (of the cerebellum), and only two showed the appearance of "pink brain." Subarachnoid ecchymoses were seen occasionally.

CHEST.-There was usually hypostatic congestion of the lungs.

OTHER ORGans.-The spleen was commonly enlarged ; malarial pigmentation was found only in one case, while smears yielded negative results for malarial parasites.

\section{Histological Examination}

(The number of cases examined is given in parentheses).

LIVER (45).-Fatty changes were a common feature ; small hæmorrhages, focal fatty degeneration, and foci of liver cell necrobiosis were seen occasionally. Specific gummatous lesions were seen in three cases only (Fig. 1). Periportal infiltration with lymphocytes, plasma cells, and occasional eosinophils was a prominent and nearly constant feature.

SPLEEN (30).-Cases with splenic enlargement showed congestion, hæmorrhage, and a moderate degree of pulp hyperplasia.

SUPRARENALS (20).-Fatty infiltration of the cortex was commonly found.

KIDNEYS (26).-The commonest findings were hyperæmia, congestion, and cloudy swelling.

Central Nervous System (60).-The entire nervous system was examined systematically.

There was only a small number of histological lesions and they were usually of low-grade intensity. Thê brain stem and white matter were as a rule more 을 involved than the cortex and the medulla oblongata Congestion and stasis were a constant feature-preo $Z$ dominantly involving the veins and the arterioles. Hæmorrhages were scanty and usually only perivascularo Capillary hæmorrhage of the "ring" type was foun only rarely (Fig. 2). There was normally no dires. evidence of endothelial damage (Fig. 3). Thrombotie $\overrightarrow{0}$ changes were rare (Fig. 4). A viscous exudation of $\doteq$ plasma, perivenous and periarterial (but not around capillaries) was a fairly constant finding (Fig. 5).

Inflammatory changes in the form of perivascular round-cell infiltration were seen in nearly all cases (Fig. 6). Patchy round-cell infiltration of the meninges was also seen (Figs. 7 and 8). Unlike the vascular changes, the round-cell infiltration was also commonly found in the cortex. All the inflammatory changes were mild. The inflammatory cells were lymphocytes, histiocytes, and plasma cells.

Parenchymatous changes were also mild (Fig. 9), and were partly secondary to perivascular hæmorrhage and viscous exudation. Nerve-cell changes were absent.

Though all the different types of lesions followed the same pattern of distribution, a considerable independence of individual lesions was observed; perivascular and round-cell infiltration were seen without hæmorrhage, and viscous exudation independent of hæmorrhage.

There was mild interstitial odema. (Gross odema with its macroscopical signs was absent.)

Some cases showed atypical features. Two showed hæmorrhagic features-one of them in the form of purpuric capillary hæmorrhages of the " ring " type in N the subcortical white matter, and the other in the form 
of a confluent capillary and perivascular hæmorrhage in the pons. Two cases showed definite perivascular demyelinating lesions not secondary to viscous exudation or hæmorrhage. The lesions were situated in the occipital white matter in one case, and in the midbrain in the other (Fig. 10).

Arsenic Contents of Tissues.-These were. determined on tissue digests with the Gutzeit method. Table VI shows the average values obtained. Our values are in good agreement with those recorded by Osterberg and Kernohan (1934).

\section{Comparison of Arsenical Encephalopathy in Indian Troops with Classical Hæmorrhagic Encephalopathy}

Comparison of "arsenical encephalopathy in Indian troops," as described here, with typical " hæmorrhagic encephalopathy," as recorded in the literature, shows a seemingly adequate pathological basis in the latter group, and macroscopical and histological findings insufficient to explain the severity of the clinical picture in the former. The pathological relationship between the two conditions is stressed by the occasional occurrence of typical hæmorrhagic cases in this series, and by two cases with typical demyelinating lesions. It is noteworthy that fully developed demyelinating lesions were seen by Dorothy Russell only in cases of four and six days' duration. One of our cases presenting fully developed demyelination is a case of " relapse " of 71 hours' duration from the onset to the fatal outcome ; the second case was of 36 hours' duration only. (The interpretation of this is somewhat confused, as the patient had been vaccinated four days before the onset of arsenical encephalopathy ; his reaction to vaccination was " modified positive.") The possibility that demyelinating lesions observed in cases of considerable duration- 4 to 6 days in the series of Dorothy Russell, 71 hours and 36 hours in this series-are the histological manifestation of functional alterations at corresponding sites, that is, the perivenous and periarterial white matter, in cases of shorter duration, has been considered. Occasional perivascular swelling of myelin sheaths and axis cylinders, independent from hæmorrhage, as well as an occasional minute focus of early perivascular necrosis, is recorded by Dorothy Russell (1937) in one case of classical hæmorrhagic arsenical encephalopathy of six hours' duration.

Arsenical encephalopathy in Indian troops is the " pathological equivalent" of classical "hæmorrhagic encephalopathy."

Non-hæmorrhagic cases of arsenical encephalopathy are recorded occasionally in the literature. It seems that the number of typical hæmorrhagic cases under record is somewhat exaggerated, as there is a tendency to regard cases with a few perivascular hæmorrhages as examples of it. In Halcrow's (1943) case " the lesions (hæmorrhages and others) present were not numerous, therefore careful searching was necessary. Some blocks of brain tissue revealed no lesions."

Visible damage to the capillary endothelium with subsequent thrombosis and rhexis of blood vessels is far more prominent in hæmorrhagic arsenical encephalopathy than in arsenical encephalopathy observed in Indian troops. Viscous perivascular exudation was seen perivenously and periarterially. It indicates loss of selective permeability of bloodvessels. It is of interest that viscous perivascular exudation was seen in the absence of gross œdema. In cases of arsenical encephalopathy with insufficient pathological findings recorded in the literature, gross odema was regarded as the cause of the clinical picture and fatal outcome. The examination of this series shows that gross œedema sufficient to produce increased intracranial pressure is not a feature of the condition.

The macroscopical and histological findings of arsenical encephalopathy in Indian troops are interpreted here rather as signs than as the cause of the clinical picture.

The presence of a circulatory disturbance is indicated by stasis, congestion, and perivascular and capillary hæmorrhage ; viscous perivascular exudation indicating the loss of selective permeability of blood vessels.

Comparison of the pathological findings and of the clinical picture in this series with the findings in classical "hæmorrhagic encephalopathy" raises some doubt that hæmorrhage itself is the only cause of the clinical picture in hæmorrhagic encephalopathy, as the clinical picture may develop in the absence of gross or purpuric hæmorrhage.

Inflammatory changes are more constant in this series than in classical hæmorrhagic encephalopathy, but the inflammatory changes are only mild. Koenigstein and Spiegel (1920) have referred to the difficulty of distinguishing between inflammatory lesions due to syphilis and inflammatory lesions due to arsenical encephalopathy in hæmorrhagic cases. The evidence of mild thickening of blood vessels with obvious perivascular round-cell infiltration, the coexistence of patchy meningeal round-cell infiltration, and the predominantly histiocytic character of the inflammatory cells, suggest in our opinion that at least part of the inflammatory lesions is the manifestation of preclinical neurosyphilis. In good agreement with this interpretation of the inflammatory lesions is the evidence in the literature that " a large proportion of the cases of syphilis show abnormalities in the fluid early in the disease" (Merritt and Fremont-Smith, 1938). It is pointed 


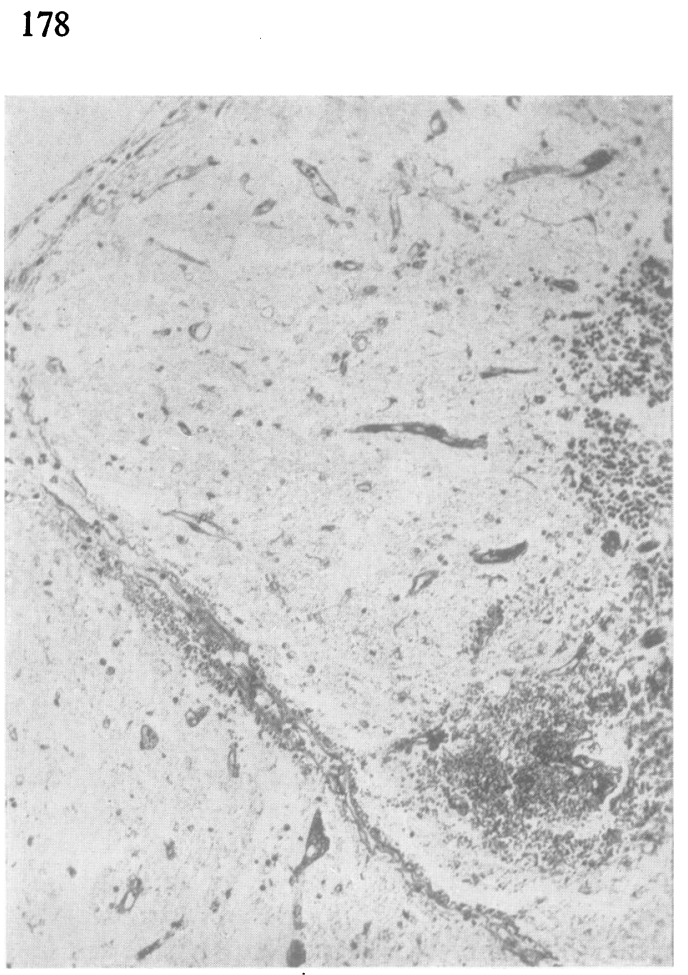

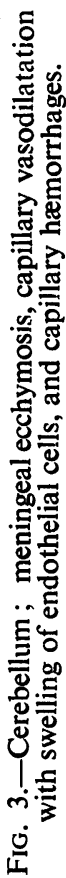
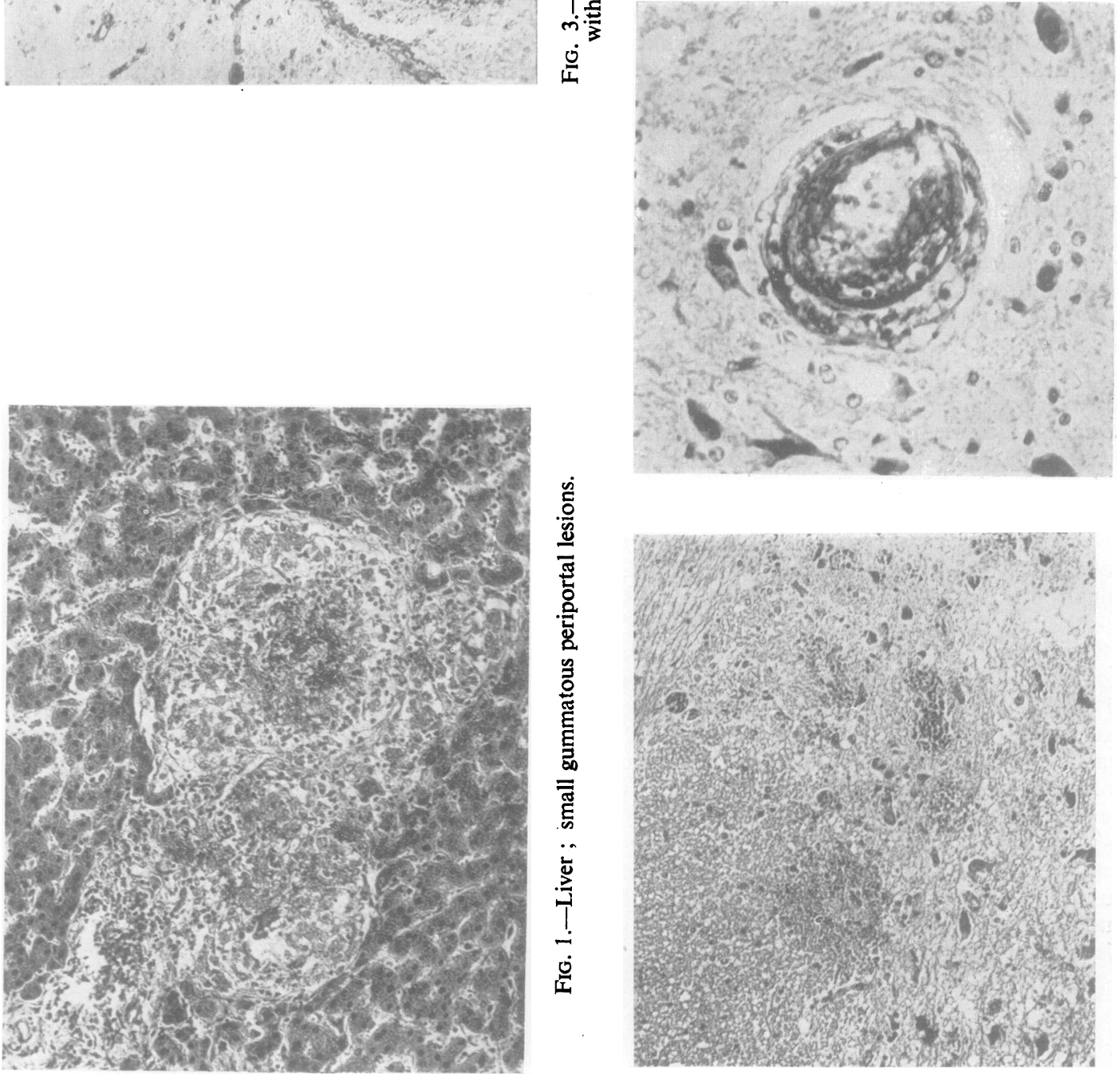

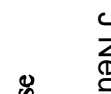

$\sum_{\mathbb{D}}^{c}$

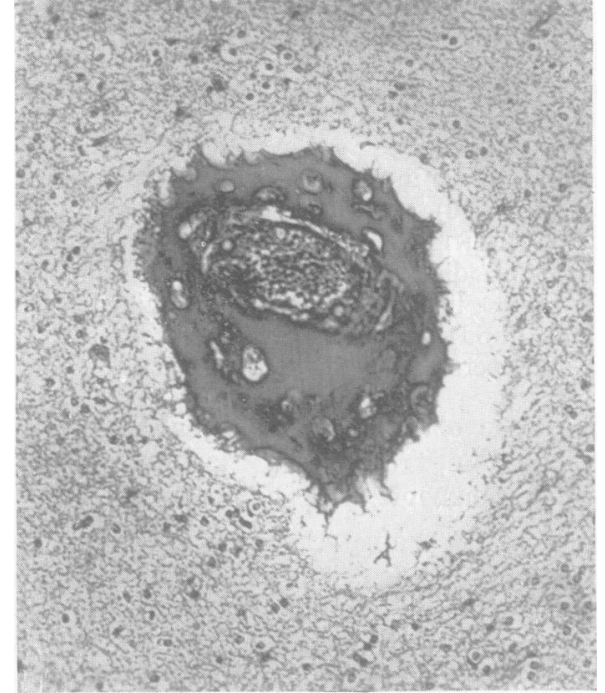

的

密. 远

है

品

营

龸育

न

ㅇ. 듬

ठํํㅇ

क.

เ

$\dot{\varphi} \stackrel{ }{\vec{I}}$

$\approx \quad \frac{\vec{\omega}}{\overline{3}}$

¿

을

통그

홍

은

흠

递

‥흔

苍产

.

$+0$

ఏ :

I

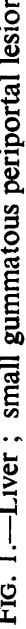

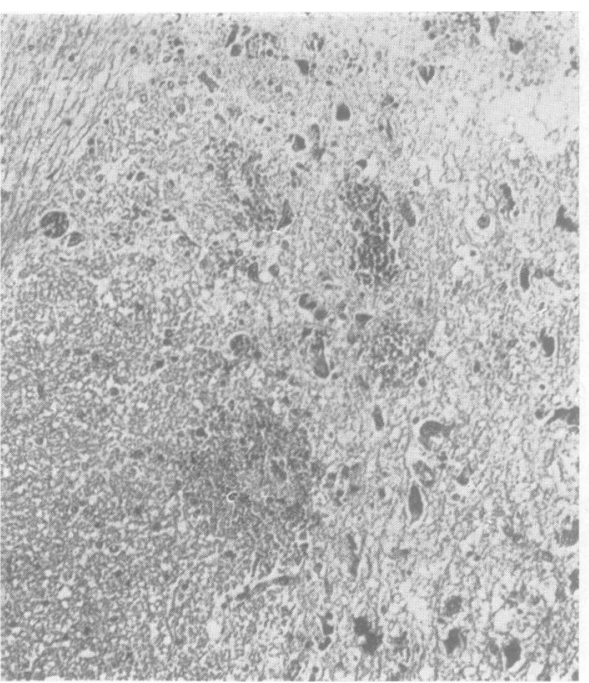

(2)

록

竹

흠

品

ò

웅

要

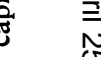

¿

ค

i

它 $\cdot \stackrel{0}{\stackrel{0}{\mathbb{D}}}$ 

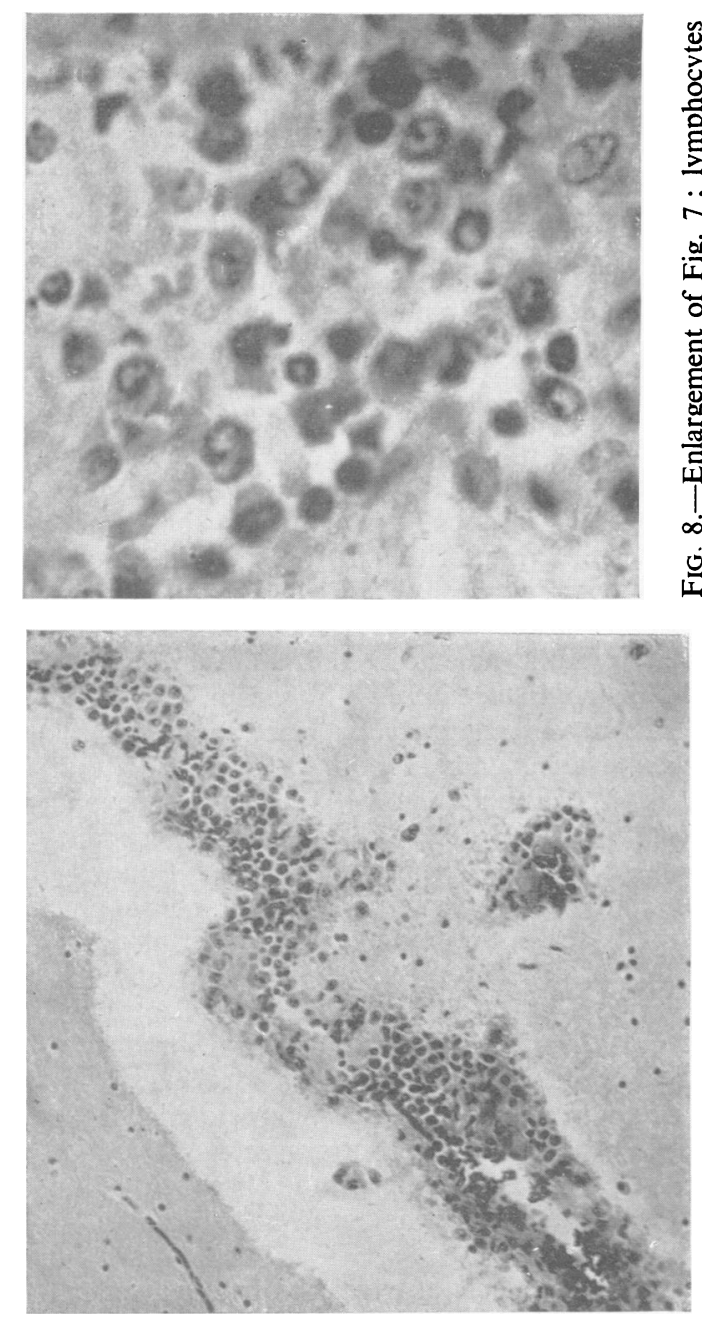

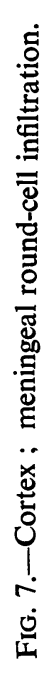
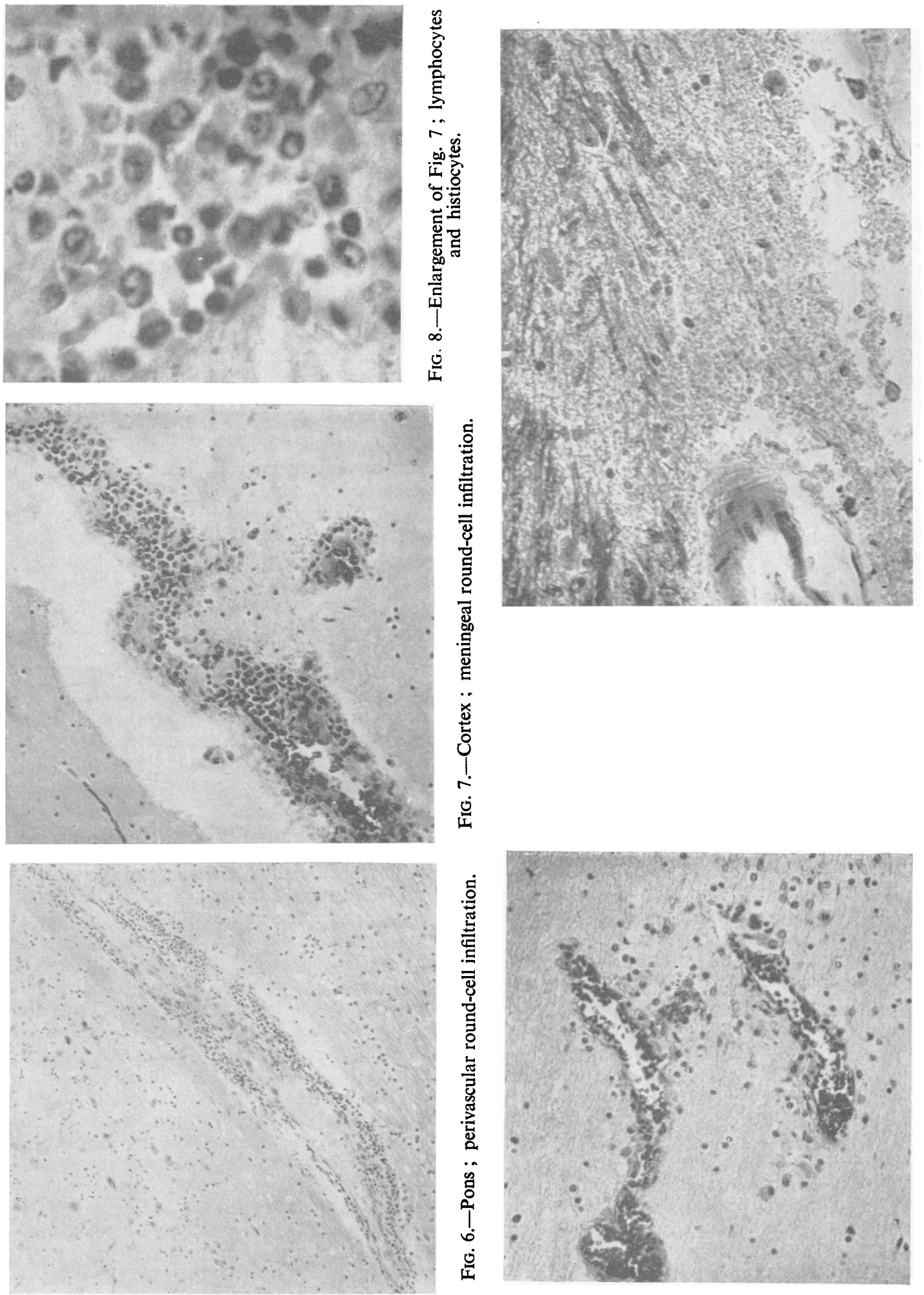

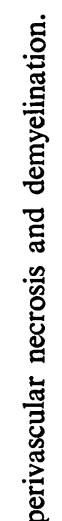


out that none of our cases shows gross evidence of meningo-vascular syphilis.

Specific lesions in the internal organs other than the central nervous system were confined to the liver. Three cases show gumma formation, and one case syphilitic hepatitis. Marked periportal roundcell infiltration was interpreted as a manifestation of syphilis.

\section{Etiology}

It seems that the facts known and some additional facts emerging from this investigation are insufficient to form the basis of a satisfactory and comprehensive explanation as to the ætiology of arsenical encephalopathy. For this reason only a short discussion of the various theories in being, and interpolation of the findings recorded in this investigation, is attempted here, the guiding principle of the discussion being to separate so far as possible the cause of the condition from its mechanism.

\section{Cause}

Activation of a pre-existing virus has been considered as the cause of arsenical encephalopathy. In other words, arsenical encephalitis would be a virus disease, the virus being pre-existent in the body of the individual and activated by the administration of a trivalent organic arsenical compound. This hypothesis bases its claims on the similarity of the picture of acute perivascular myelinoclasis and hæmorrhagic encephalitis following various virus infections or antirabic treatment, with the picture of hæmorrhagic and demyelinating arsenical encephalopathy. It is admitted that the exact relationship between the original virus infections and the subsequent encephalitis in the group of diseases referred to is not known. No additional facts have been found here to give more weight to the infection theory, so far as activation of a pre-existing virus is concerned.

Sterilization of syringes after each injection had no influence on the incidence rate of arsenical encephalopathy, and when two cases of arsenical encephalopathy occurred on the same day a subsequent check on the order in which the patients were injected revealed that the patients belonged to different batches. There seems to be no proof that a virus is carried by the syringe.

Various authors have pointed to the complex of Jarisch Herxheimer's reaction as the cause of arsenical encephalopathy. Our material gives no evidence in this direction. If the condition is Jarisch Herxheimer's reaction it should follow twenty-four hours after the first injection of the N.A.B., and if this be dispensed with one would expect that the cerebrospinal fluid would be Wassermann-positive in these cases at the time of the arsenical encephalopathy. Out of twenty-five cases examined, the cerebrospinal fluid Wassermann was negative in 17 and positive in 8 . For that reason it is thought that Jarisch Herxheimer's reaction is not the cause of arsenical encephalopathy in this series.

Authors who believe that acute perivascular myelinoclasis following various infections is the effect of sensitization, and not a virus disease in itself, expressed the opinion that arsenical encephalopathy is the result of sensitization against arsenic. Various points are in favour of this assumption, as the time of onset of arsenical encephalopathy after the first injection is the same as the common time of onset of acute perivascular myelinoclasis or hæmorrhagic encephalitis after the original virus infection ; also the interval between the onset of serum sickness and administration of serum is of comparable order. Trivalent organic arsenical compounds, especially if administered together with serum, produced sensitization and anaphylactic reaction in guineapigs (Landsteiner and Jacobs, 1936). For that reason sensitization cannot be excluded beyond $\vec{\circ}$ doubt as a causative factor of arsenical encephalo- i pathy. Reports of untoward accidents following administration of arsenic compounds in patiente who survived an attack of arsenical encephalopath are recorded in the literature. An observation t the contrary was put at our disposal by Captain $\mathrm{L}$ ( Cohen, R.A.M.C. After having had an attack of arsenical encephalopathy a patient received errop $\exists$ eously an injection of N.A.B., with no ill effects. A second case treated with intramuscular injection of a trivalent arsenical compound subsequent to an attack of arsenical encephalopathy showed also no untoward effects.

Finally, toxic effects of trivalent organic arsenical compounds have also been regarded as the cause of arsenical encephalopathy. Osterberg and Kernohan (1934) reported " relatively high arsenic contents," 을 especially of the white matter of the cerebrum, in $\overrightarrow{\overrightarrow{0}}$ cases of hæmorrhagic arsenical encephalopathy. "It has been suggested by Voegtlin and his coworkers that the same mechanism by which the arsenicals are lethal to parasites (spirochætes) is apparently concerned in their toxicity for the tissues of the host" (quoted from Goodman and Gilman, 1941).

After one injection of arsphenamine 50 to 70 per cent. of the arsenic is excreted within one week, and $₹$ this is a determinant of the weekly interval between 을 injections in patients (Goodman and Gilman, 1941). The standard treatment of syphilis introduced on this basis-weekly injections of trivalent organic arsenicals-gives a high percentage of cures with a or minimum of untoward effects and fatalities. 
In the endeavour to shorten the time of treatment and to ensure a higher percentage of cures of syphilis, massive and continuous treatment with N.A.B. and mapharside was introduced. Increased spirocidal toxicity obtained by these means was accompanied by increased tissue toxicity.

The Army treatment of syphilis with bi-weekly injections is a compromise between massive treatment and standard treatment with weekly injections. In this investigation it was found that the incidence rate of arsenical encephalopathy in certain groups of Indians-Madrassis and Mahrattas-was significantly higher with bi-weekly than with weekly injections ; this fact is relevant to any hypothesis of causation.

It is often recorded in the literature that arsenical encephalopathy is as common with high as with low doses of N.A.B. Our material does not allow any statement to be made to this effect, as the dosage was standardized according to body weight and for that reason comparable in the different dosage groups.

The following line of thought has been taken here. The basis of the weekly standard treatment was the knowledge that a high percentage of arsenic (50 to 70 per cent.) is excreted within one week after injection. Treatment with weekly injections avoids accumulation of arsenic. It appears logical that if treatment is given at bi-weekly intervals, with either the same dose or even with a somewhat lower dose of N.A.B., a higher level of arsenic will be maintained for a longer time. As bi-weekly treatment is apparently associated with an increased incidence rate of arsenical encephalopathy, it is concluded that the maintenance of a high level of N.A.B. increases the incidence rate of arsenical encephalopathy. Such an effect of a relatively high arsenic concentration maintained in the body for a comparatively long time indicates a causative relationship between the incidence rate of arsenical encephalopathy and the frequency of injections of N.A.B.

\section{Mechanism}

It is generally agreed that the mechanism involved in hæmorrhagic encephalopathy is vascular damage ; "capillary encephalorrhagy" is the term proposed by Globus and Ginsberg (1933). Also thrombosis has been regarded as the cause of hæmorrhagic and necrotic lesions; damage to the endothelium of blood vessels with swelling and fatty degeneration is recorded. The mechanism of perivenous and peri-arterial demyelination is not understood. A toxin has been held responsible by Dorothy Russell. In rare non-hæmorrhagic cases œdema and vasoparalysis (Scheinker, 1944) have been regarded since Ehrlich (1914) as the cause of the clinical picture and fatal outcome.
An attempt to analyse the lesions observed in this series as part of the mechanism producing arsenical encephalopathy shows the following : the presence of vascular and circulatory disturbances is indicated by stasis, congestion, hæmorrhage, and occasional thrombosis ; capillary hæmorrhages, usually indicating a severe vascular and circulatory disturbance, are scarce.

An important feature of the condition is the presence of perivascular viscous exudation of plasma indicating loss of selective permeability of blood vessels. This is also indicated by the high protein values of the cerebrospinal fluid observed in arsenical encephalopathy, and their importance is stressed by the observation that the average protein content of the cerebrospinal fluid has been significantly lower in cases which recovered than in cases with fatal outcome. It is stressed that this loss of selective permeability recorded here is not associated with gross œdema, the discrepancy between the amount of perivascular viscous exudation and the absence of the effects of severe œdema is obvious. Not only is the intracranial pressure, determined by lumbar puncture, within normal limits, but also the fundus is devoid of papillodema, and the anatomical manifestations of increased intracranial pressure, that is, pressure cones and flattened gyri, are also absent. It seems of interest that the intracranial pressure was often below average, the blood pressure being normal.

The following working hypothesis may be attempted, although no special claims can be laid on' it. Administration of N.A.B. produces damage to cerebral blood vessels, resulting in loss of selective permeability. Subsequently N.A.B. and split products of N.A.B. penetrate into the nervous tissue, mainly perivenously and periarterially, and interfere there with oxydation systems of the parenchyma. In hæmorrhagic cases the vascular damage is more prominent in the form of hæmorrhage and œdema ; in non-hæmorrhagic cases the invisible tissue toxic effect is more prominent and may manifest itself at later stages of the disease as perivascular necrosis and demyelination.

\section{Summary}

1. Arsenical encephalopathy in Indian troops is the pathological equivalent of classical hæmorrhagic arsenical encephalopathy ; it has the same time of onset and the same clinical picture as the classical condition, but it differs by a comparatively high incidence rate and by the absence of gross hæmorrhagic or purpuric lesions. The relationship to the classical condition is stressed by occasional typical hæmorrhagic cases and by cases showing demyelination. 
2. The " racial " incidence of arsenical encephalopathy is high in Indians; it is considered that part of it is " social" incidence.

3. An attack of malaria during or shortly before antisyphilitic treatment is an important factor in increasing the incidence of arsenical encephalopathy.

4. The incidence rate of arsenical encephalopathy in Indian troops treated with weekly injections of N.A.B. is of the same order as the incidence rate in Indian civilians.

5. The increase in the incidence rate of arsenical encephalopathy in Indian troops, as compared with Indian civilians and observed since 1943, is the effect of the treatment of syphilis with bi-weekly injections of N.A.B.

6. The increased incidence rate of arsenical encephalopathy following bi-weekly injections of N.A.B. is not proportionate in all provincial groups of Indian troops. The incidence rate is significantly higher in Madrassis and Mahrattas, and only moderately increased in Indians from other provinces.

7. The incidence rate of arsenical encephalopathy in sero-positive primary and secondary syphilis is not higher than in sero-negative primary syphilis. The higher incidence rate of arsenical encephalopathy in sero-negative primary syphilis as compared with the two other groups is still below statistical significance in this series.

8. Four successive stages of the clinical picture can be separated. The first three stages are reversible, all cases reaching the fourth stage-coma -are fatal.

9. The protein content of the cerebrospinal fluid in arsenical encephalopathy is usually greatly increased without proportionate increase of the cell count ; the average protein content in cases which recover is significantly below the average in fatal cases. The high protein content of the cerebrospinal fluid is interpreted as the manifestation of loss of selective permeability of blood vessels.

10. The arsenic content of the brain in this series was relatively high, and of the same order as reported by Osterberg and Kernohan (1934) in cases of classical hæmorrhagic arsenical encephalopathy.

11. The tissue pathological findings are signs rather than the cause of the condition. They indicate vascular damage, circulatory disturbance, and loss of selective permeability of blood vessels.

12. Gross œdema, increasing the intracranial pressure, is not a feature of the condition. This is substantiated by the absence of pailloedema, the average pressure of the cerebrospinal fluid at lumbar puncture, and the absence of pressure cones.

13. The fact that a relatively high level of N.A.B. is maintained for a comparatively long time if treatment is given at bi-weekly intervals, together with the subsequently increased incidence rate of arsenical encephalopathy, indicates a causativo relationship between the level of arsenic maintained in the tissues, the frequency of injections of N.A.B. and the incidence rate of arsenical encephalopathy

14. Arsenical encephalopathy subsequent to standardized form of antisyphilitic treatment is considered here as a tissue toxic effect of trivalen? organic arsenical compounds in persons predisposef racially, socially (nutrition), and individually (e.g.: malaria). Whereas vascular damage is more prominent in cases of classical hæmorrhagic encephalopathy, functional and eventual anatomicef damage to the parenchyma was more conspicuou in arsenical encephalopathy in Indian troops.

We are indebted to the Director of Medical Servicesto India Command, for permission to publish the paper to Brigadiers Cameron, Denny-Brown, Harris, McAlpine, Platt, and Prebble, and to Col. Hall, and Lieut.-Col. Garland, Lieut.-Col. Goadby, and Lieut.-Col. McDonald for their interest in the work. We are also indebted to the venereal disease specialists and pathologists of the Army in India for their co-operation in forwarding case records and post-mortem material. A series of case sheets and specimens has been forwarded to us by Majo Lacy. Dr. Trashawalla was responsible for the medicat care of many of the patients. Thanks are also dueto Sgt. Conlay, Sgt. Gould, and Pte. Trinder for the technical work in histology and biochemistry.

\section{REFERENCES}

Cole, H. N., De Wolf, H., McCuskey, J. M., Miskjianio H. G., Williamson, G.' S., Rauschkolb, J. R., Rucho R. O., and Clark, T. (1931). J. Amer. med. Ass., ef? 897. (Quoted after Russell, D.)

Ehrlich, P. (1914). Brit. med. J., 6, 1044.

Glaser, M. A., and Imerman, C. P., and S. W. (1935) Amer. J. med. Sci., 189, 64.

Globus, J. H., and Ginsberg, S. W. (1933). Arch. Neurol. Psychiat., Chicago., 30, 1226. (Quoted aftę Russell, D.)

Goodman, L., and Gilman, A. (1941). "The Pharmo cological basis of Therapeutics." McMillan. New York.

Halcrow, J. P. A. (1943). Brit. med. J., $1,663$.

Koenigstein, H., and Spiegel, E. (1920). Z. ges. Neurol Psychiat., 62, 44.

Krainer, L. (1944). " Third Medical Division's Con3 ference, Southern Army, Poona." Medical Researc Council War Memorandum No. 10(a).

Landsteiner, K., and Jacobs, J. (1936). J. exp. Med 64, 717 .

Lydon, F. L. (1944). Brit. J. vener. Dis., 20, 87.

McCarrison, R. (1921). "Studies in Deficiency' Diseases." Oxford University Press.

Merritt, H. H., and Fremont-Smith, F. (1938). "The Cerebrospinal Fluid." Saunders. Philadelphia.

Osterberg, A. E., and Kernohan, J. W. (1934). Amer? J. Clin. Path., 4, 362.

Pollack, E., and Riehl, G. Jr. (1930). Jhrb. Pschiat? Neur., 47, 99.

Rajam, R. V., and Rao, N. V. (1939). Indian med를. Gaz. 74, 24.

Russeli, D. S. (1937). J. Path. Bact., 45, 357.

Scheinker, I. M. (1944). Arch. Path., 37, 91. 